\title{
Karakteristik Mekanik Panel Honeycomb Sandwich Berbahan Komposit Fibreglass dengan Dimensi Cell-Pitch 40mm dan Cell-Height 30mm
}

\author{
Marsono, Ali, Nico Luwis \\ Jurusan Teknik Mesin, Fakultas Teknik Industri, ITENAS, Bandung \\ Email: marsono@itenas.ac.id
}

\begin{abstract}
ABSTRAK
Rekayasa struktur honeycomb sandwich dalam pengembangan material banyak telah dimanfaatkan karena memiliki kekuatan struktur yang relatif tinggi dengan bobot material yang ringan. Material dengan rekayasa struktur honeycomb cocok digunakan pada mobil hemat energi, untuk meningkatkan efesiensi energi. Dalam penelitian ini dibuat panel honeycomb sandwich berbahan komposit serat kaca (fibreglass) dan matirks resin. Panel ini nantinya akan diterapkan pada rangka kendaraan hemat energi. Tiga panel honeycomb sandwich dibuat dengan variasi pada ketebalan dinding sel terutama ditujukan untuk mengetahui pengaruh ketebalan dinding sel terhadap kekuatan dan kekakuan panel honeycomb sandwich. Variasi ketebalan dinding sel didapatkan dari variasi penerapan jumlah lapisan fibreglass pada dinding sel honeycomb, yaitu 2 lapis, 4 lapis dan 6 lapis fibreglass. Hasil pengujian bending menunjukkan bahwa panel honeycomb sandwich dengan ketebalan dinding sel terbesar, yaitu dengan 6 lapisan fibreglass, memberikan kekuatan lentur terbesar yaitu $3,774 \mathrm{~kg} / \mathrm{mm}^{2}$, dan kekakuan tertinggi, yaitu $21,48 \mathrm{~kg} / \mathrm{mm}$.
\end{abstract}

Kata kunci: honeycomb sandwich, komposit fibreglass, kekuatan lentur, kekakuan.

\begin{abstract}
Engineering of honeycomb sandwich structure in the materials development has been highly utilized because of its high structural strength with lightweight material. Honeycomb structure material is suitable for use in energy-efficient cars, to increase energy efficiency. In this research, sandwich honeycomb panel were made from fibreglass composite with resin as matrices. This panel will be applied to the frame of energy-efficient vehicle. Three sandwich honeycomb panels were made with variations in cell wall thickness. These variations are primarily intended to determine the effect of cell wall thickness to the flexural strength and stiffness of the honeycomb sandwich panel. Variations in cell wall thickness were obtained from variations in the application of fibreglass layers on honeycomb cell walls, which are 2 layers, 4 layers and 6 layers of fibreglass. The bending test results show that the honeycomb sandwich panel with the largest cell wall thickness, which has 6 layers of fibreglass, provides the greatest flexural strength of $3.774 \mathrm{~kg} / \mathrm{mm}^{2}$, and the highest stiffness of $21.48 \mathrm{~kg} / \mathrm{mm}$.
\end{abstract}

Keywords: honeycomb sandwich,fibreglass composite, flexurall strength, stiffness. 


\section{PENDAHULUAN}

Chassis atau rangka merupakan bagian dari mobil yang berfungsi menahan atau memikul beban kendaraan [1]. Konstruksi rangka chasis itu sendiri harus memiliki kekuatan, ringan dan mempunyai nilai kelenturan [2]. Sistem chasis monocoque dan stressed skin memiliki pendekatan struktural dengan pembebanan pada kulit luar. Teknologi yang dikembangkan mulai tahun 1962 itu membawa revolusi dalam pengmbangan chasis mobil balap formula. Banyak tim yang dengan cepat mengadopsi chasis model ini yang kemudian dikombinasikan dengan sandwich honeycomb aluminium. Penggunaan komposist serat karbon juga ikut membantu perkembanan chasis monocoque ini [3]

Pengembangan mobil listrik di Indonesia sangat terbuka lebar, yang mana mobil listrik ini dapat menjadi solusi untuk masalah pencemaran lingkungan akibat emisi karbondioksida dan emisi sulfur-dioksida akibat dari pembakaran bahan bakar fosil pada kendaraan bermotor. Meningkatnya penggunaan kendaraan bermotor juga akan mempercepat penipisan cadangan bahan bakar fosil dan mempercepat terjadinya krisis energi. Salah satu usaha yang dapat dilakukan adalah mengurangi pemakaian bahan bakar fosil untuk transportasi dan menggantikannya dengan energi listrik. Mobil listrik akan menjadi salah satu solusi dalam memperlambat terjadinya krisis energy [1].

Dalam penelitian ini akan dilakukan pembuatan dan pengujian karakteristik mekanik pada panel struktur hexagonal honeycomb sandwich yang nantinya akan diaplikasikan untuk chasis mobil listrik, tipe monocoque, karena mobil listrik membutuhkan body maupun chasis yang ringan dan kuat. Bahan yang dipilih untuk chasis mobil lisrik ini adalah material komposit, yaitu perpaduan serat fibreglass dan resin.

Untuk mengetahui karakteristik mekanik dari panel hexagonal struktur honeycomb sandwich ini, akan dilakukan uji bending yang diterapkan untuk beberapa variasi ketebalan dinding sel-struktur honeycomb melalui variasi jumlah lapisan serat fibreglass, yaitu 2 lapir, 4 lapis dan 6 lapis fibreglass

\section{METODOLOGI}

\subsection{Honeycomb sandwich}

Panel Honeycomb Sandwich merupakan salah satu yang paling berharga dalam inovasi pengembangan Teknik Struktur untuk indsutri komposit (material komposit). Panel honeycomb Sandwich digunakan untuk rancangan dan konstruksi sistem transportasi ringan sebagaimanan yang digunakan pada satelit, pesawat terbang, dan kereta cepat. Pengurangan berat struktural menjadi pertimbangan utama dalam penggunaaan konstruksi sandwich ini. Konstruksi panel sandwich menjadi pilihan yang lebih baik daripaka metoda peningkatan kekuatan dengan menambah ketebalan material. Konstruksi sandwich memberikan efisiensi struktural yang sangat baik, yaitu, dengan rasio kekuatan terhadap berat yang tinggi. Keunggulan lain yang ditawarkan oleh konstruksi sandwich adalah menghilangkan pengelasan, kualitas insulasi superior dan fleksibilitas desain [4]

Konstruksi panel struktur sandwich terdiri dari dua lapisan kulit tipis yang dipisahkan oleh material inti (core). Beberapa jenis bentuk inti telah banyak diterapkan pada konstruksi struktur sandwich. Salah satu bentuk inti yang paling populer adalah bentuk sarang lebah (honeycomb) yang dibentuk dari lembaran yang sangat tipis dalam bentuk sel-sel heksagonal yang tegak lurus terhadap lapisan kulit [4]

\subsection{Rancangan Panel Struktur Honeycomb Sandwich}

Penelitian ini dilakukan dengan tujuan untuk mengetahui karakteristik mekanik honeycomb sandwich, terutama keluatan lentur dan kekakuannya. Struktur honeycomb sandwich yang akan diuji dalam 
penelitian ini akan dibuat dari bahan komposit fibreglass. Material komposit fibreglass menjadi pilihan yang cukup baik karena bobotnya yang ringan dan teknik pembuatanya yang relatif lebih mudah, juga karena harga yang murah dan sangat mudah didapatkan.

Spesifikasi dari struktur honeycomb yang akan dibuat dan diuji dalam penelitian ini memiliki detail ukuran cell-pitch 40mm dan cell-size 36,64mm seperti Gambar 1.

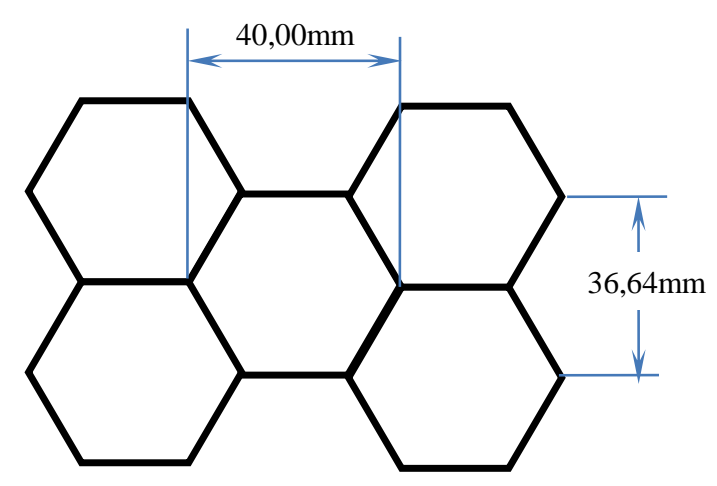

Gambar 1. Dimensi cell-pitch dan cell-size

Adapun ukuran panel struktur honeycomb yang akan diuji memiliki panjang (length) 500mm lebar (width) $\pm 200 \mathrm{~mm}$ dan tebal/tinggi (cell-height) $30 \mathrm{~mm}$, mengacu pada nomenklatur penel honeycomb yang telihat pada Gambar 2.

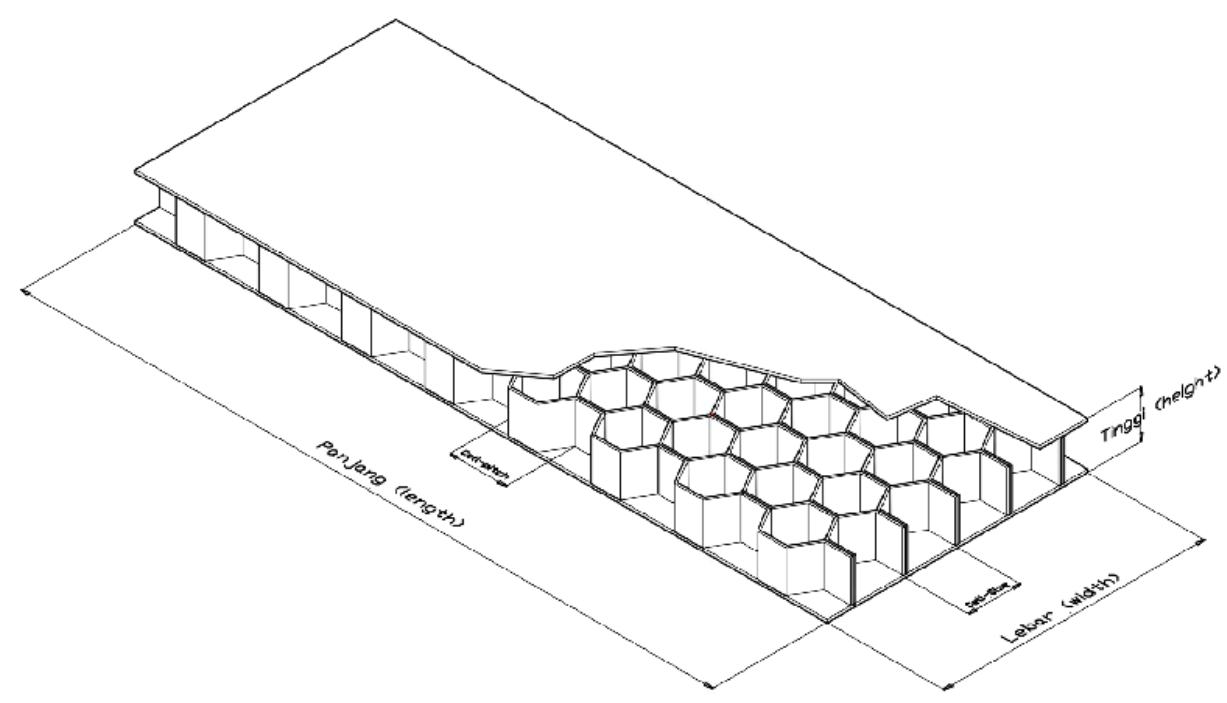

Gambar 2 Nomenklatur Panel Honeycomb Sandwich

Pengujian panel honeycomb akan dilakukan untuk beberapa specimen dengan variasi ketebalan dinding cell. Variasi ketebalan dinding cell diperoleh dengan penggunaan jumlah lapisan serat fibreglass yang berbeda, yaitu 2 lapis, 4 lapis dan 6 lapis fibreglass.

\subsection{Pembuatan Specimen panel Struktur Honeycomb}

Panel struktur honeycomb sandwich dibuat dengan cara menyusun lembaran bergelombang (corrugated sheet) lapis demi lapis. Lembaran-lembaran bergelombang yang disusun bertumpuk akan membentuk 
sel segieman (heksagonal). Lembaran bergelombang ini dibuat dengan menggunakan cetakan berbahan hard-nylon agar resin perkat tidak menempel pada cetakan dan lembaran bergelombang dapat dikeluarkan dari cetakan dengan mudah. Dan selanjutnya, lembaran-lembaran bergelombang akan disusun seperti yang terlihat pada Gambar 3 hingga membentuk panel struktur honeycomb.

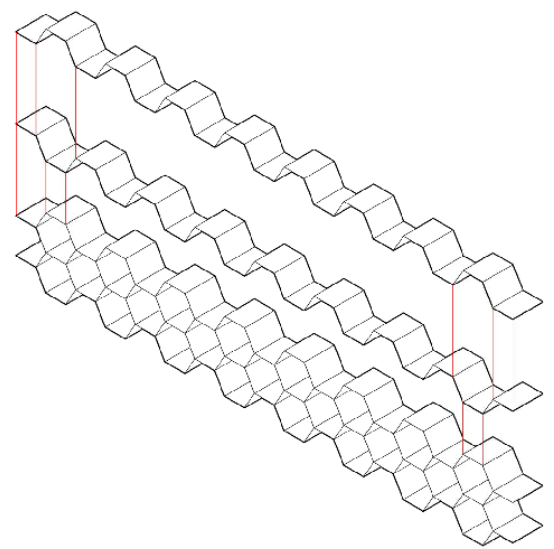

Gambar 3 Penyusunan lembaran bergelombang hingga membentuk struktur honeycomb

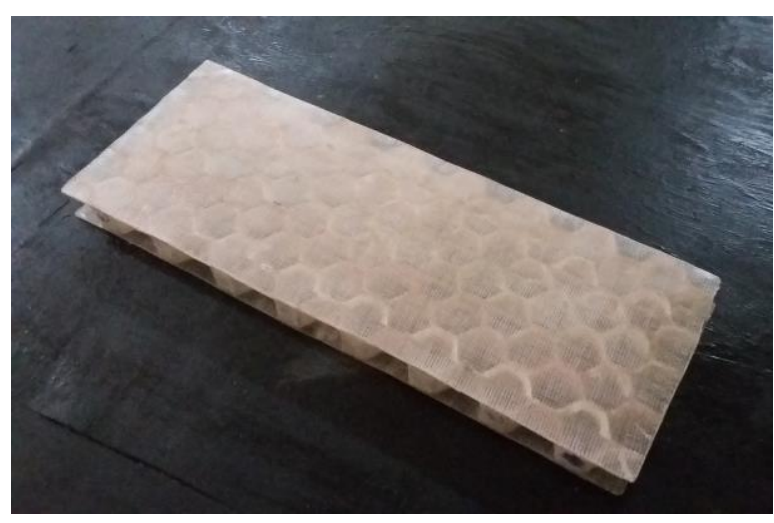

Gambar 4. Panel honeycomb sandwich yang telah jadi

Susuan lembaran bergelombang yang telah jadi selanjutnya ditutup dengan faceskin yang terbuat dari 2 lapis fibreglass dan resin di kedua sisi hingga didapatkan bentuk akhir panel struktur honeycomb sandwich seperti yang terlihat pada Gambar 4.

Penggunaan jumlah lapisan serat (fibreglass) yang berbeda pada saat pembuatan lembaran bergelombang menyebabkan perbedaan ketebalan pada dinding sel honeycomb. Dari proses pembuatan panel honeycomb telah yang dilakukan, didapatkan ukuran ketebalan dinding sel honeycomb untuk penggunaan 3 variasi jumlah lapisan fibreglass, yaitu 2 lapis, 4 lapis dan 6 lapis. Perbedaam ketebalan masing-masing sel honeycomb terlihat pada Gambar 5a, 5b, dan 5c.

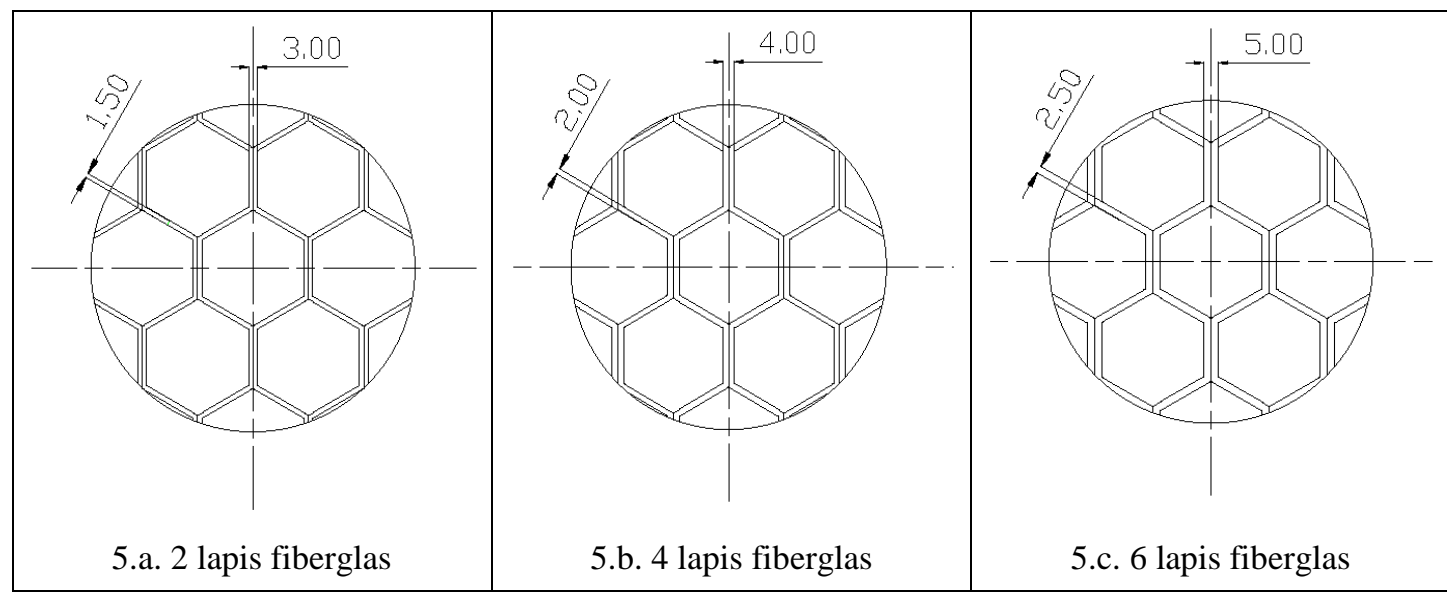

Gambar 5. Ketebalan dinding sel heksagonal

Perbedaan ketebalan dinding sel honeycomb, terutama pada bagian sambungan lembaran bergelombang berdampak kepada perbedaan lebar setiap panel honeycomb, sementara panjang dan tebal panel tidak berbeda. Adapun variasi lebar panel struktur honeycomb terlihat pada Gambar 6a, 6b, dan 6c. 


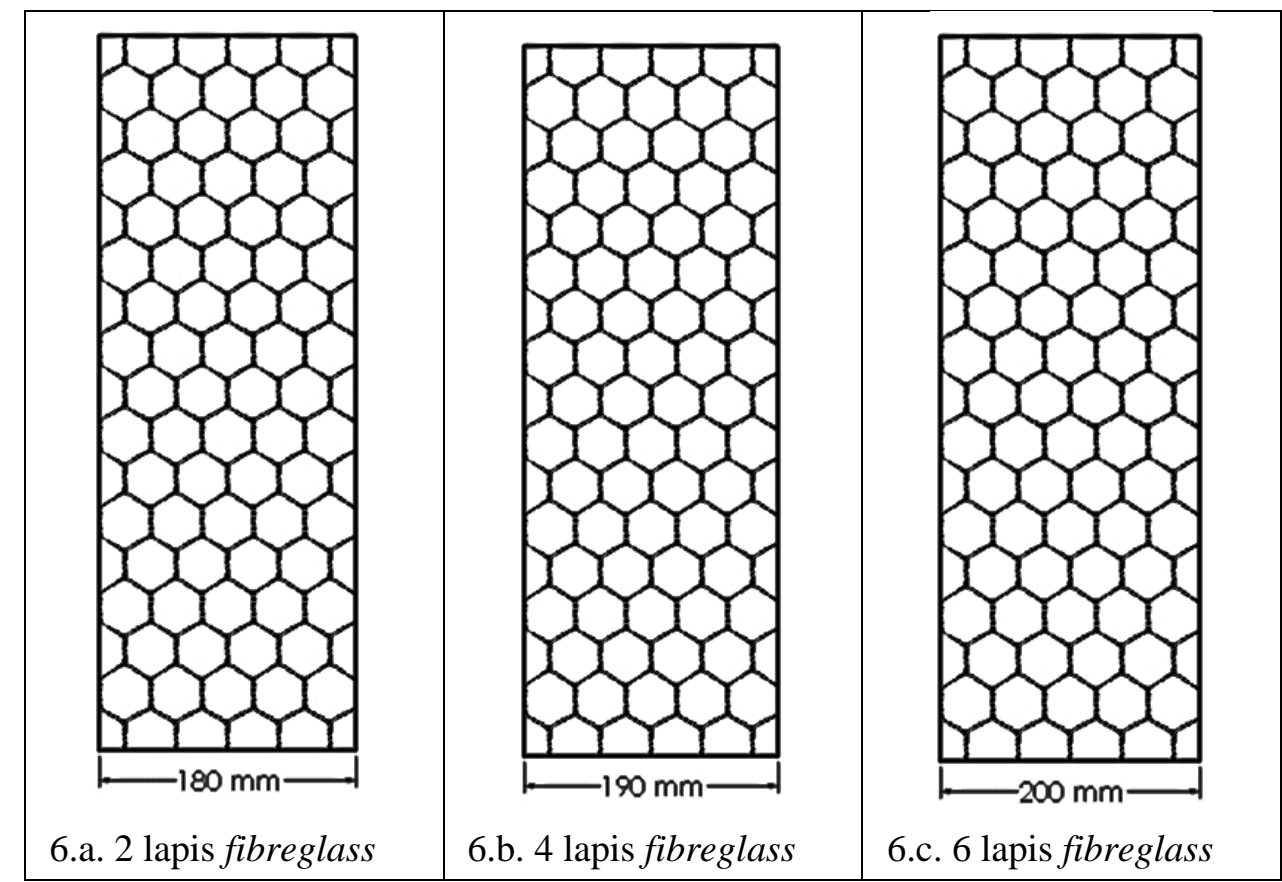

Gambar 6. Variasi lebar panel honeycomb hasil pembuatan

Dalam pembuatan panel honeycomb sandwich, dilakukan beberapa penimbangan, yaitu penimbangan bahan serat yang dipakai dan berat panel yang telah jadi. Penimbangan ini dilakukan untuk menemukan rasio berat fibreglass terhadap berat resin. Berat panel honeycomb sandwich juga diperlukan untuk menghitung massa jenis panel. Data tentang berat serat (fibreglass), berat resin dan berat total dari masing-masing panel terlihat pada Tabel 1 . Pada Tabel 1 juga ditampilkan persentase berat serat (fibreglass) dan berat resin. Massa jenis panel honeycomb sandwich dihitung berdasarkan berat dan dimensi panel seperti yang terlihat pada Tabel 2

Tabel 1. Berat serat (fibreglass), berat resin, berat total, serta persentase berat serat fibreglass dan resin spesimen panel honeycomb Sandwich.

\begin{tabular}{ccccccc}
\hline \multirow{2}{*}{ No } & Variasi & \multicolumn{2}{c}{ Berat serat } & \multicolumn{2}{c}{ Berat Resin } & \multirow{2}{*}{$\begin{array}{c}\text { Berat } \\
\text { Total }\end{array}$} \\
\cline { 3 - 6 } & Lapisan & $(\mathbf{g r})$ & $\mathbf{( \% )}$ & $\mathbf{( g r )}$ & $(\boldsymbol{\%})$ & $($ gram) \\
\hline 1 & 2 lapis & 410 & 65 & 250 & 35 & 630 \\
\hline 2 & 4 lapis & 630 & 77 & 215 & 23 & 815 \\
\hline 3 & 6 lapis & 890 & 82 & 220 & 18 & 1080 \\
\hline
\end{tabular}

Tabel 2. Perhitungan masssa jenis panel honeycomb

\begin{tabular}{|c|c|c|c|c|c|c|c|}
\hline \multirow[t]{2}{*}{ No } & \multirow{2}{*}{$\begin{array}{l}\text { Variasi } \\
\text { Lapisan }\end{array}$} & \multirow{2}{*}{$\begin{array}{c}\text { Berat total } \\
\text { panel } \\
\text { (gram) }\end{array}$} & \multicolumn{3}{|c|}{$\begin{array}{c}\text { Dimensi panel } \\
\text { (Panjang x Lebar x Tebal) } \\
(\mathbf{m m})\end{array}$} & \multirow{2}{*}{$\begin{array}{l}\text { Volume panel } \\
-\quad\left(\mathbf{m}^{3}\right)\end{array}$} & \multirow{2}{*}{$\begin{array}{c}\text { Massa jenis } \\
\text { panel } \\
\rho=\mathbf{m} / \mathbf{v}\left(\mathrm{kg} / \mathrm{m}^{3}\right.\end{array}$} \\
\hline & & & $\mathbf{P}(\mathbf{m m})$ & $\mathbf{L}(\mathbf{m m})$ & $\mathbf{T}(\mathbf{m m})$ & & \\
\hline 1 & 2 lapis & 630 & 500 & 180 & 34 & 0.0031 & 205.8 \\
\hline 2 & 4 lapis & 815 & 500 & 190 & 34 & 0.0032 & 252.3 \\
\hline 3 & 6 lapis & 1080 & 500 & 200 & 34 & 0.0034 & 317.6 \\
\hline
\end{tabular}


Berdasarkan dimensi yang didapatkan dari specimen panel honeycomb yang telah jadi, dapat dihitung Inersia penampang untuk masing-masing panel struktur honeycomb. Inersia penampang ini dihitung di bagian yang paling lemah, atau di bagian yang memiliki luas paling kecil, yaitu di bagian tengah panel pada arah memanjang. Di titik ini juga nantinya akan dikenakan beban pada saat pengujian bending.

\subsection{Standar Pengujian Panel Honeycomb Sandwich}

Pengujian panel honeycomb sandwich dilakukan untuk mengetahui karakteristik mekanik dari panel tersebut. Karakteristik mekanik yang ingin diketahui dari panel honeycomb sandwich adalah kekuatan lentur (flexural strength) dan kekakuan (stiffness). Standar yang digunakan dalam pengujian honeycomb sandwich adalah ASTM C393-00 Standard Test Method for Flexural Properties of Sandwich Constructions. (ASTM 393-00, 2000) [5].

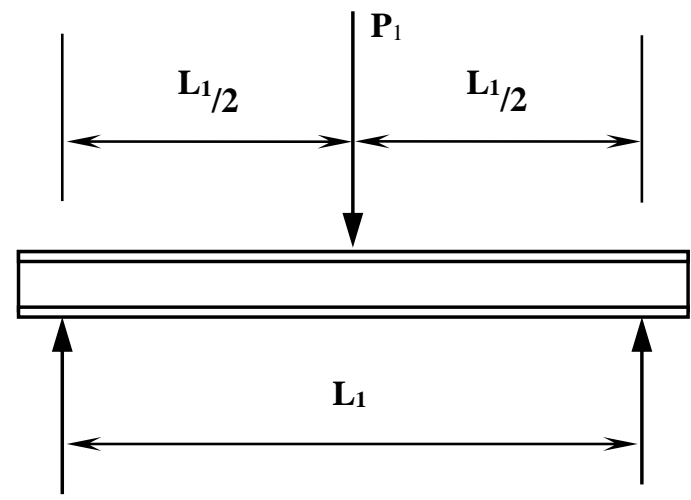

Gambar 7. Pembebanan satu titik (ASTM C393-00, 2000)

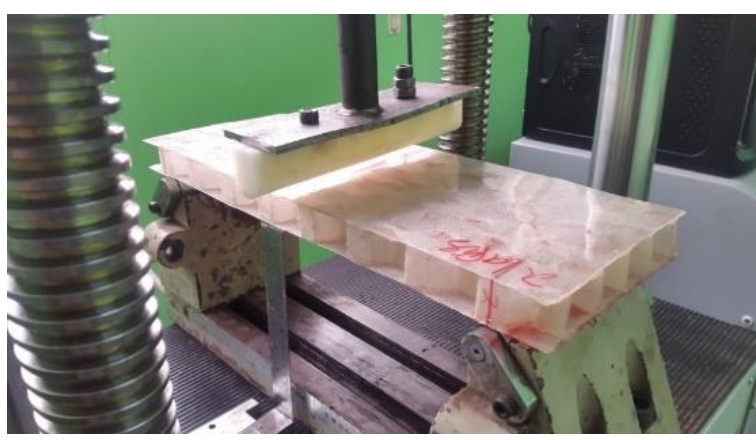

Gambar 8. Pengujian Panel Honeycomb Sandwich menggunakan mesin Gotech Testing Machine

Dengan memperhatikan standar pengujian ASTM C393-00, maka dirancang instalasi uji lentur atau bending dengan pembebanan di satu titik, sebagaimana yang terlihat pada Gambar 7. Adapun jarak antara tumpuan $\left(\mathrm{L}_{1}\right)$ adalah $420 \mathrm{~mm}$ dan beban tepat berada di tengah-tengah jarak tumpuan $\left(\mathrm{L}_{1} / 2\right)$. Pengujian lentur ini dilakukan dengan menggunakan mesin Gotech Testing Machine, Model GT-7001LS10 dengan kapasitas $100 \mathrm{kN}$, seperti yang terlihat pada Gambar 8.

\subsection{Karakteristik fisik}

\section{HASIL DAN PEMBAHSAN}

Pengukuran dan pengujian yang dilakukan telah memberikan data tentang beberapa karakteristik fisik dari panel honeycomb sandwich, yaitu komposisi (perbandingan) berat antara serat (fibreglass) dan matriks ( resin), serta massa jenis dari panel honeycomb sandwich tersebut. Karakteristik fisik dari panel honeycomb sandwich terilhat pada Tabel 3. 
Tabel 3. Karakteristik fisik panel honeycomb sandwich

\begin{tabular}{cccccccc}
\hline \multirow{2}{*}{ No } & \multirow{2}{*}{$\begin{array}{c}\text { Lariasi } \\
\text { Lapisan }\end{array}$} & \multicolumn{2}{c}{ Perbandingan Serat dan Resin } & \multicolumn{2}{c}{$\begin{array}{c}\text { Berat panel } \\
\text { (gram) }\end{array}$} & $\begin{array}{c}\text { Massa jenis } \\
\left(\mathbf{k g} / \mathbf{m}^{\mathbf{3}}\right)\end{array}$ \\
\cline { 3 - 6 } & $\begin{array}{c}\text { Serat } \\
\text { Berat }\end{array}$ & $\%$ berat & $\begin{array}{c}\text { Resin } \\
\text { (gram) }\end{array}$ & $\%$ berat & & \\
\hline 1 & 2 & 410 & $65 \%$ & 220 & $35 \%$ & 630 & 205.8 \\
\hline 2 & 4 & 630 & $77 \%$ & 185 & $23 \%$ & 815 & 252.3 \\
\hline 3 & 6 & 890 & $82 \%$ & 190 & $18 \%$ & 1080 & 317.6 \\
\hline
\end{tabular}

Tabel 3 memperlihatkan adanya penurunan persentase penggunaan matriks (resin) terhadap penambahan jumlah lapisan serat. Hal ini menunjukkan adanya pemanfaatan resin yang lebih efisien pada jumlah lapisan serat yang lebih banyak.

Penambahan lapisan fibreglass pada dinding sel honeycomb berdampak kepada penambahan ketebalan dinding sel honeycomb, seperti yang terlihat pada Gambar 5.1, 5.b dan 5.c. Selanjutnya, penambahan ketebalan dinding sel juga akan berdampak kepada kenaikan berat panel honeycomb sandwich dan penambahan lebar panel honeycomb sandwich (Gambar 6.a, 6.b dan 6.c). Penambahan lebar panel tentunya berdampak kepada volume panel, sebagaimana terlihat pada Tabel 2.

Kenaikan berat panel sebagai fungsi dari penambahan ketebalan dinding honeycomb lebih besar dibandingkan kenaikan volume panel sehingga massa jenis panel honeycomb juga ikut meningkat walaupun tidak sebesar kenaikan berat panel honeycomb. Hal ini terlihat pada Tabel 4. Jika dilihat dari sisi ini, maka sebaiknya honeycomb dibuat dengan diinding yang lebih tipis untuk mendapatkan bobot yang ringan dan massa jenis yang kecil, tetapi tetap tidak boleh melupakan faktor kekuatan.

Tabel 4. Kenaikan berat dan massa jenis terhadap jumlah lapisan

\begin{tabular}{cccccccc}
\hline No & $\begin{array}{c}\text { Variasi } \\
\text { Lapisan }\end{array}$ & $\begin{array}{c}\text { Berat } \\
\text { panel } \\
(\text { gram) }\end{array}$ & $\begin{array}{c}\text { Kenaikan } \\
\text { berat }\end{array}$ & $\begin{array}{c}\text { Volume } \\
\text { panel } \\
\left(\mathbf{m}^{\mathbf{2}}\right)\end{array}$ & $\begin{array}{c}\text { Kenaikan } \\
\text { Volume }\end{array}$ & $\begin{array}{c}\text { Massa jenis } \\
\left(\mathbf{k g} / \mathbf{m}^{\mathbf{3}}\right)\end{array}$ & $\begin{array}{c}\text { Kenaikan } \\
\text { massa jenis }\end{array}$ \\
\hline 1 & 2 & 630 & 1 & 0.0031 & 1 & 205.8 & 1 \\
\hline 2 & 4 & 815 & 1,29 & 0.0032 & 1.03 & 252.3 & 1,23 \\
\hline 3 & 6 & 1080 & 1.71 & 0.0034 & 1.09 & 317.6 & 1,54 \\
\hline
\end{tabular}

\subsection{Karakteristik Mekanik}

Karakteritik mekanik panel honeycomb sandwich didapatkan dari uji bending sesuai ASTM C393-00 Standard Test Method for Flexural Properties of Sandwich Constructions. Data yang didapatkan dari pengujian ini adalah beban maksimum yang dapat ditahan oleh panel honeycomb sandwich serta defleksi maksimum yang terjadi pada saat beban maksimum terjadi. Hasil uji bending terlihat pada Tabel 5 .

Tabel 5. Hasil pengujian specimen

\begin{tabular}{|c|c|c|c|}
\hline No & $\begin{array}{l}\text { Variasi } \\
\text { Lapisan }\end{array}$ & $\begin{array}{c}\text { Beban maksimum } \\
(\mathrm{kg})\end{array}$ & $\begin{array}{c}\text { Defleksi maksimum ( } \delta \text { ) } \\
(\mathrm{mm})\end{array}$ \\
\hline 1 & 2 lapis & 137.3 & 11 \\
\hline 2 & 4 lapis & 213.37 & 14 \\
\hline 3 & 6 lapis & 386.71 & 18 \\
\hline
\end{tabular}




\section{Kekuatan Lentur Panel}

Data yang diperoleh dari uji bending yang berupa beban lentur maksimum serta hasil perhitungan momen inersia penampang panel, diolah untuk mendapatkan kekuatan lentur maksimum dari masingmasing panel dengan persamaan (1) sebagai berikut [6]:

$$
\sigma=\frac{M \times C}{I_{x x}}
$$

Dari perhitungan yang dilakukan, diperoleh kekuatan lentur maksimum $\left(\sigma_{\max }\right)$ dari masing-masing panel seperti yang terlihat pada tabel 6. Peningkatan kekuatan lentur sebagai efek dari jumlah lapisan fibreglass pada dinding sel honeycomb diperlihatkan pada grafik kekuatan lentur maksimum pada gambar 9.

Tabel 6. Perhitungan kekuatan lentur maksimum

\begin{tabular}{ccccccc}
\hline No & $\begin{array}{c}\text { Lapisan } \\
\text { fibreglass }\end{array}$ & $\begin{array}{c}\text { Beban } \\
\text { Maksimum } \\
(\mathbf{k g})\end{array}$ & $\begin{array}{c}\text { Lengan } \\
\text { Momen } \\
(\mathbf{m m})\end{array}$ & $\begin{array}{c}\mathbf{C} \\
(\mathbf{m m})\end{array}$ & $\begin{array}{c}\text { Penampang Inersia } \\
\mathbf{I}_{\mathbf{x x}} \\
\left(\mathbf{m m}^{\mathbf{4}}\right)\end{array}$ & $\begin{array}{c}\boldsymbol{\sigma}_{\mathbf{m a x}} \\
\left(\mathbf{k g} / \mathbf{m m}^{\mathbf{2}}\right)\end{array}$ \\
\hline 1 & 2 & 137,30 & 210 & 17 & 218.310 & 1,123 \\
\hline 2 & 4 & 213,37 & 210 & 17 & 239.813 & 2,269 \\
\hline 3 & 6 & 386,71 & 210 & 17 & 261.317 & 3,774 \\
\hline
\end{tabular}

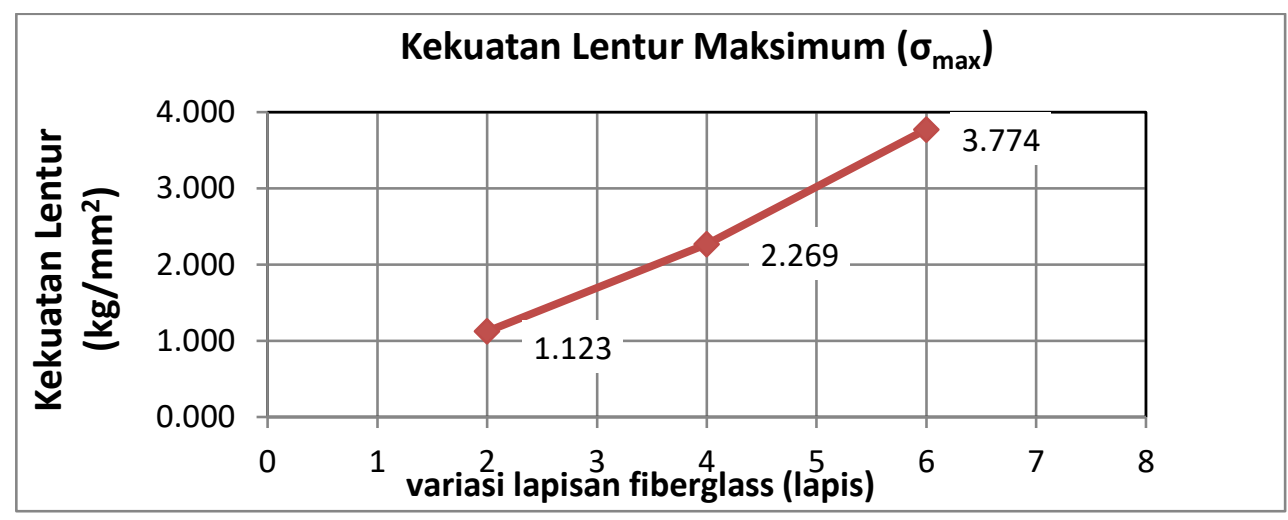

Gambar 9. Grafik Kekuatan lentur terhadap Variasi lapisan fibreglass

Uji bending yang dilakukan pada panel boneycomb sandwich dengan variasi tebal dinding sel dengan 2, 4 dan 6 lapisan fibreglass menunjukkan peningkatan kekuatan yang cenderung mengikuti fungsi linier. Hal ini sejalan dengan persamaan inersia penampang dari bentuk persegi yang berbanding lurus dengan tebal penampang persegi.

\section{Kekakuan panel}

Kekakuan panel dihitung berdasarkan gaya maksimum yang dapat ditahan oleh panel honeycomb sandwich dan defleksi yang terjadi pada panel tersebut, dengan persamaan (2) sebagai berikut [6] :

$K=\frac{P}{\delta}=\frac{6 E I}{a^{2}(3 L-a)}$

Dari perhitungan yang dilakukan diperoleh kekakuan panel seperti yang terlihat pada Tabel 7 Peningkatan kekakuan panel sebagai efek dari jumlah lapisan fibreglass diperlihatkan pada grafik kekakuan pada Gambar 10. 
Tabel 7. Kekakuan panel honeycomb sandwich

\begin{tabular}{cccc}
\hline $\begin{array}{c}\text { Lapisan } \\
\text { fibreglass }\end{array}$ & $\begin{array}{c}\text { beban maksimum } \\
(\mathbf{k g})\end{array}$ & $\begin{array}{c}\boldsymbol{\delta} \\
(\mathbf{m m})\end{array}$ & $\begin{array}{c}\text { kekakuan } \\
(\mathbf{k g} / \mathbf{m m})\end{array}$ \\
\hline 2 & 137,30 & 11 & 12,48 \\
\hline 4 & 213,37 & 14 & 15,24 \\
\hline 6 & 386,71 & 18 & 21,48 \\
\hline
\end{tabular}

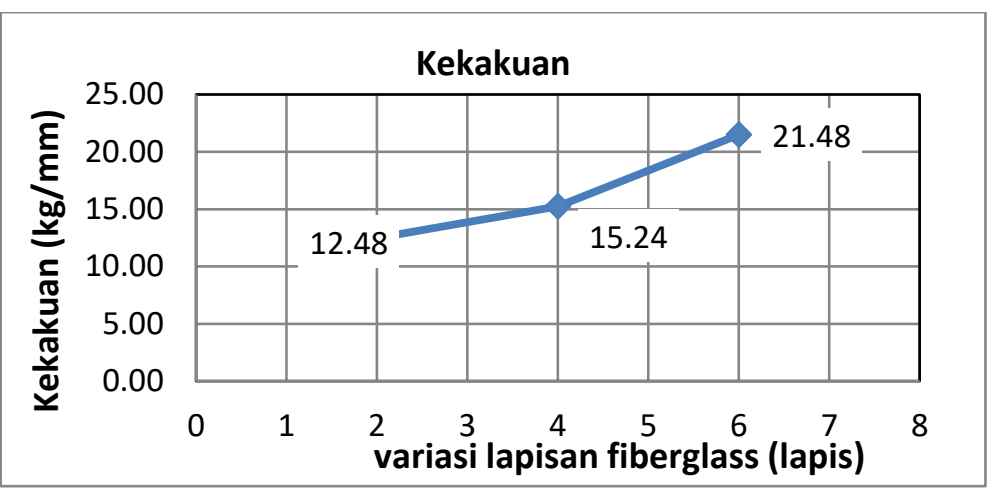

Gambar 10. Grafik Kekakuan terhadap Variasi lapisan fibreglass

Penambahan jumlah lapisan fibreglass pada dinding sel honeycomb memperlihatkan adanya peningkatan kekakuan panel honeycomb sandwich. Hasil pengujian dan perhtiungan yang dilakukan, menunjukkan bahwa peningkatan kekakuan panel sebagai efek dari penambahan ketebalan dinding sel honeycomb sandwich juga masih cenderung mengikuti fungsi linier.

\section{KESIMPULAN}

Hasil penelitian menunjukkan bahwa massa jenis terkecil honeycomb sandwich didapatkan pada panel dengan ketebalan sel yang paling rendah dengan 2 lapis fibreglass, yang mana didapatkan massa jenis sebesar $205.8 \mathrm{~kg} / \mathrm{mm}^{3}$.

Kekuatan lentur dan kekakuan terbesar ditemukan pada panel dengan ketebalan dinding sel terbesar, yaitu ketebalan dinding sel dengan 6 lapis fibreglass. Pada ketebalan dinding tersebut kekuatan lentur yang dicapai adalah $3,774 \mathrm{~kg} / \mathrm{mm}^{2}$ sedangkan kekakuan yang dicapai adalah $21,48 \mathrm{~kg} / \mathrm{mm}$.

Pengujian yang telah dilakukan terhadap 3 macam panel honeycomb sandwich juga menunjukkan bahwa penambahan penggunaan lapisan fibreglass pada dinding sel honeycomb akan meningkatkan kakuatan lentur dan kekakuan panel pada fungsi linier.

\section{DAFTAR PUSTAKA}

[1] Purnomo, Sigit J., Pratama, Bangkit H., Hakim, Lukman N., Nurofik, Pambudi Setya, 2107, Uji Eksperimental Kinerja Mobil Listrik, Prosiding SNATIF Ke -4 Tahun 2017, Fakultas Teknik Universitas Muria Kudus, ISBN: 978-602-1180-50-1, pp.679-686

[2] Ali Sadikin, 2013, Perancangan Rangka Chasis Mobil Listrik Untuk 4 Penumpang Menggunakan Software 3D Siemens NX8, [skripsi], Fakultas Teknik Universitas Negeri Semarang 
[3] Piyush Ram Shahade, Akshay Kumar Kaware, 2014, Structural Performance Analysis of Formula SAE Car, International Journal of Pure and Applied Research in Engineering and Technology, IJPRET, 2014; Volume 2 (9): pp307-320.

[4] K.Kantha Rao1, K. Jayathirtha Rao, A.G.Sarwade, M.Sarath Chandra, 2012, International Journal of Engineering Research and Applications (IJERA) ISSN: 2248-9622 www.ijera.com Vol. 2, Issue 3, May-Jun 2012, pp. 365-374

[5] Anonim, 2000 ASTM C393-00 - Standard Test Method for Flexural Properties of Sandwich Constructions.

[6] Mott, Robert L., 2002 “Applied Strength of Materials" $4^{\text {th }}$ Edition, Prentice-Hall, New jersey 